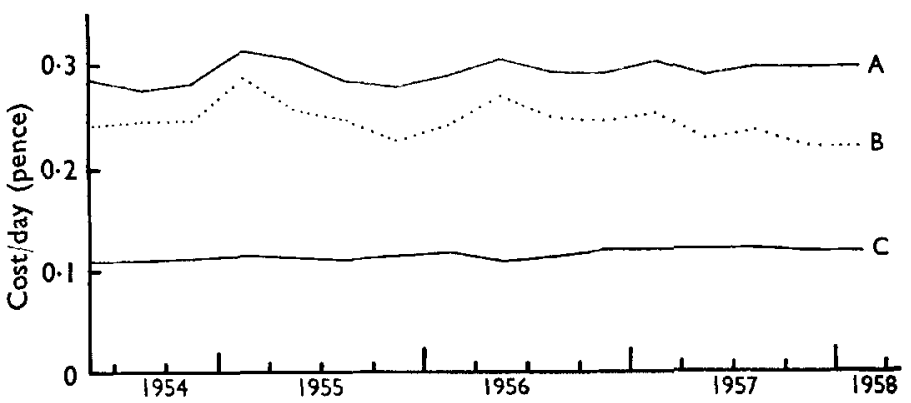

Fig. 3. Comparative cost of supplements for laying pullets from 1954 to 1958 . The figures represent the cost/bird/day for supplements only after adjustment for cereals replaced.

A, $7 \%$ white-fish meal in a ration containing $14.5 \%$ total protein; $\mathrm{B}, 8.8 \%$ groundnut meal in a ration containing $14 \%$ total protein; $\mathrm{C}, 5.1 \%$ white-fish meal in a ration containing $11 \%$ total protein.

rations. Rosenberg, Waddell \& Baldini (r955) found, for example, that the addition of free DL-methionine to diets of maize and soya-bean meal containing $5-15 \%$ fish meal, and apparently already possessing adequate methionine for normal growth, produced a significant increase in weight gain and food utilization in chick starters. Similar work on British types of ration is, however, lacking, and it is impossible to estimate the extent to which such supplementation with the pure amino-acid might be economical here. DL-methionine is now readily available and comparatively cheap, and it is certainly conceivable that a worth-while saving in white-fish meal could be realized.

It should be emphasized that the possibility of replacing fish meal is suggested mainly because of the inadequacy of home supplies. There is no doubt of the value of fish meal in rations for young animals, birds and sows, and providing that price allows, it should be included.

\title{
REFERENCES
}

Carpenter, K. J. \& Duckworth, J. (195I). F. agric. Sci. 4I, 297.

Carpenter, K. J., Duckworth, J. \& Ellinger, G. M. (1954). F. agric. Sci. 44, 340.

Carpenter, K. J., Duckworth, J., Lucas, I. A. M., Shrimpton, D. H. \& Walker, D. M. (I956). f. agric. Sci. 47, 435.

Evans, R. E. (1952). F. agric. Sci. 42, 438 .

Rosenberg, H. R., Waddell, J. \& Baldini, J. T. (1955). Poult, Sci. 34, 114.

Woodman, H. E. \& Evans, R. E. (I948). F. agric. Sci. 38, 5 I.

Woodman, H. E. \& Evans, R. E. (I95I). F. agric. Sci. 41, I02.

\section{Some consumer aspects of fish as food}

By C. L. Cutring, Humber Laboratory, Department of Scientific and Industrial Research, Hull

Fish consumption varies widely from $45 \mathrm{~kg} / \mathrm{head} /$ year in the Philippines and other islands of eastern Asia to less than $\mathrm{I} \mathrm{kg}$ in parts of central Europe and other inland areas (Food and Agriculture Organization o he United Nations, I949; Cutting, 
I95I). Distribution within countries is irregular, consumption being higher as a rule in coastal areas where fish is cheaper and fresher. Furthermore, there is a greater variation of strong personal likes and dislikes with fish than with other protein foods.

\section{Types of presentation}

Fish can be consumed in four main ways: (I) fresh, substantially as caught (including frozen fish); (2) processed, with the object of preservation, e.g. by salting, smoking, drying, canning or by allowing it to autolyse to a liquid; (3) 'neutralized' by some chemical process, e.g. solvent extraction of protein or hydrogenation of oil, to conceal its fishy origin; (4) indirectly, after use for nourishing animals or plants.

Fish is also used as food for pets and for certain non-nutritional purposes, e.g. fish oils can be used for detergents, paint, linoleum, leather-dressing.

Fresh fish is usually eaten after cooking. Parasitic infections may occur where it is eaten raw (Hitchcock, I950). Processed fish can be eaten 'raw'. The saltiness of salted fish is accentuated by cooking.

In the days before good roads and railways, and the use of ice to delay spoilage, made possible the rapid distribution of fresh fish (Cutting, 1955), the staple items of fish in the diet were heavily salted, smoked and dried products, such as red herring, stockfish and salt cod. These were mostly excessively salty and tough and possessed peculiar flavours resulting from bacterial and enzyme activity during the processing. Although the Middle Ages depended on such products, Elizabethan literature (e.g. Shakespeare, ${ }^{1598}$ ) makes it clear that they were eaten because nothing else was available for most people. Although there is still a sizeable export of these traditional products, they are no longer relished in the more economically advanced countries. Most people, if given the choice, prefer the blander flavour of fresh fish, or the mildly smoked and relatively perishable kipper and finnan haddock, although there are possibilities of developing a luxury market in certain of the milder types of cured speciality. However, in less developed countries with poorer communications, particularly those with hot climates, widespread preservation of fish in unaltered form by chilling and freezing is not yet economically possible, so that reliance on salting, smoking and drying in some form may well continue for some time to come.

Although fish protein was used as an egg substitute in Germany in wartime (Myles, Reay \& Farrer, 1945) it is chiefly in underdeveloped countries that attempts are being made to create a consumption of edible fish flours (Cutting \& Bakken, I957; Food and Agriculture Organization of the United Nations: Nutrition Division, 1958). In these experiments fish protein is presented as a filler, with no characteristic fishy flavour, so that the consumer is unaware of its origin.

At the other extreme, ordinary fish meals, as used for animal fodder, although still perhaps a little scorched and bitter rather than fishy in flavour (in spite of technical improvements in process and product in recent years) are perfectly acceptable where it is the dietary custom to add small pieces of highly flavoured fish products more as a condiment than as nutriment to an otherwise drab cereal dish. Thus, in West Africa, there is a market for crude fish meal made locally (Johnson, 1955) and an encouraging reception has been given to trial consignments 
of British herring meal (Herring Industry Board, 1957). In between these two extremes, it is possible by less severe drying conditions to produce a fairly stable, superior dried-fish product, in which there is no need to disguise the mildly fishy flavour (Cutting, Reay \& Shewan, 1956).

Enough information is available on likely consumer reactions in undernourished areas throughout the world to suggest that, in spite of conservatism and strong regional idiosyncrasies, there is a sufficient volume and variety of potential demand to assimilate, somewhere or other, all the fish that could be made available, in whatever form it were preserved and transported, from complete lack of character at one end of the scale to extreme putridity at the other. The only question at issue is whether the price that indigenous populations could afford to pay would meet the costs involved.

\section{Consumer attitudes to fish in Britain}

In Britain, in spite of the fact that some types of fish are relatively cheap, consumption, after a postwar boom when meat was short, has fallen since $195^{\circ}$, although much less sharply than meat consumption has been rising (Central Statistical Office, I957). At present about 100,000 tons (or 10\%) of our white fish and herring cannot be sold as food, so that it can be concluded that the market for fish in its present state is almost saturated, although perhaps not all outlets have as yet been penetrated sufficiently vigorously. Fish shops account for about one-half of the total trade in fish, and fish-and-chip shops for about one-quarter, although as the latter use the cheaper grades, particularly distant-water cod fillets, they probably handle more than one-third of the fish eaten, along with nearly a million tons of potatoes and about 80,000 tons of fats and oils (White Fish Authority, 1956; Anonymous, 1957).

The average consumption of fish is now only about $6 \mathrm{oz}$. ( $170 \mathrm{~g}) / \mathrm{head} / \mathrm{week}$, of which less than $\mathrm{I}$ oz. is smoked. There are relatively wide variations due to area, income level and family composition, children particularly depressing consumption. About one-half of all households buy white fish in any one week, but only $4 \%$ buy herrings, and kippers and smoked white fish are each bought by $9 \%$ (Ministry of Food: National Food Survey Committee, 1953; Ministry of Agriculture, Fisheries and Food: National Food Survey Committee, I956a, $b$, 1957, 1958). An independent survey estimated that of the $90 \%$ of the housewives who buy fish, $40 \%$ buy it at least twice a week, thus accounting for $66 \%$ of sales, and ascertained that a fair proportion of housewives were critical of the quality of fish and the cleanliness of retail shops (Anonymous, r 956 ).

A recent survey (European Productivity Agency of the Organisation for European Economic Co-operation, 1957) sums up the consumer attitude to fish over most of western Europe as follows: 'Many people eat fish more by habit and because they think they need it, rather than because they have any special desire for this particular food. It is only in areas where the fish supplied has been of supreme quality for a long time that it is esteemed. . . But in areas where the standard of quality is usually low, the customer puts up with it. The fact that the consumer is sometimes indifferent to the quality has created the opinion that the present quality 
is good enough. ... There is a considerable measure of support for the supposition that more fish would be purchased if its quality were more reliable.

\section{Factors affecting the quality of fish as food}

The quality of fish as food is determined both by its intrinsic condition in vivo and the extrinsic post-mortem changes. The biological condition of the fish is the result of numerous factors. Thus, natural factors determine the characteristic flavour of sole and salmon as compared with cod and herring, and opinions may differ as to which is preferable. Geographical factors affect the size of the fish and the extent of parasitic-worm infestation. Pathological conditions of protozoal, bacterial or fungal origin affect acceptability, as also do certain peculiar conditions which are nutrimental in origin. The annual sexual spawning cycle affects the plumpness of white fish and the oil of fatty species, and has less easily definable effects on flavour. None of these intrinsic factors can be controlled except by learning when and where not to catch fish. The general extrinsic factors are related to various types of spoilage produced by bacterial decomposition, chemical changes, particularly oxidation of fat leading to rancidity, and physical effects, such as excessive desiccation, which makes texture unpalatable. All these deteriorative changes have a high temperature coefficient and they can therefore be retarded by controlling temperature, principally by the effective use of ice or cold storage. There must be considerable variation in the tolerance of consumers for some of the off-flavours produced, particularly rancidity, which in some instances may even, within limits, have come to be accepted as part of the characteristic flavour of certain products.

\section{The quality of fresh and frozen fish in Britain}

Over half of our white fish is landed by distant-water trawlers anything from 5 to about 15 days after catching. Ehrenberg \& Shewan (1953) and Shewan \& Ehrenberg ( 1957 ) have shown that the course of spoilage of iced white fish, such as cod and haddock, can be divided organoleptically into four phases: 'excellent,' 0-6 days; 'good,' 6-1o days; 'stale,' ro-15 days; 'inedible,' over ${ }_{5} 5$ days. Although several thousand tons (amounting to about $0.5 \%$ ) are condemned annually by the port sanitary inspectors as 'unfit, unsound or unwholesome', and a similar quantity is seized at Billingsgate and other inland markets, obviously a good deal of indifferent fish is passed on to the public. Canadian standards are appreciably higher, and fish over about Io days in ice is condemned. The temperature at which fish is maintained during distribution is the most important factor determining its keeping quality, the rate of spoilage being approximately doubled by every $5^{\circ}$ increase in temperature. A recent survey of fish temperature from landing to retailing has indicated that in summer time spoilage is liable to be nearly three times as rapid as it would be if fish were chilled at $0^{\circ}$ throughout. The mean of several thousand measurements on fish displayed in fish shops was $13^{\circ}$ and temperatures as high as $22^{\circ}$ were recorded. The effect of this sort of treatment on fish leaving the port after I $_{5}$ days on the trawler may well be a factor adversely affecting its sales. 
Good retail-shop management is more important than hygienic fittings. Thus, in $195^{\circ}$ east London shops sold fresher fish than those in the West End (Reay, $195^{\mathrm{I}}$ ) and that sold by stalls was better still, owing no doubt to more rapid turnover of stock.

Throughout the trade, fish is bought and sold almost entirely on the basis of appearance, not of taste, or even odour. The idea of quality control in the sense used in other food industries is only just beginning to be appreciated (Cutting \& Burgess, I958), hastened by the growth of branded frozen fish, which is dearer but more reliable than 'fresh' fish. The pre-packaging of wet fish for sale in self-service stores would only be an improvement if there were strict control over the times and temperatures involved in distribution.

\section{The quality of smoked fish in Britain}

Sales of smoked fish have declined in recent years to about $2 \mathrm{lb}$./head/year, which is about $30 \%$ of the postwar peak of 1947 or $50 \%$ of prewar. Although numerous reasons may be adduced, indifferent quality of a proportion of the product is a contributory factor. Although fish smoking itself is an extremely primitive process, the chief technological reasons for the fall-off in quality are firstly, that the trend towards ever milder flavours has led to a reduction in shelf-life, masked by the use of artificial colouring to conserve the traditional appearance; and secondly, the fact that full employment has resulted in kippering being converted from a seasonal and migratory industry into one based all the year round at a fixed port, notably Hull. As a result of a request by the industry for a grading scheme, it has been possible recently to sample a substantial proportion of British kipper production. Kippers, both raw and cooked, were scored by a panel on a 'ten-points' scale, in which 7 was the 'pass' mark, and 6 a 'just fail' or 'commercial pass', and anything below 4 was so unpalatable as to be 'uneatable'. Of over 2,000 batches sampled as they left the producers in Hull during $1956-7,25 \%$ scored over 7.5 , both raw and cooked, and could therefore be rated 'good'; $47 \%$ fell between 7.5 and 6 and were 'passable'; $23 \%$ were between 6 and 4 and were 'unsatisfactory'; and $5 \%$ came below 4 and could only be described as 'bad'.

During transport to inland wholesale markets and retailing, smoked fish is not usually chilled, and temperatures of over $80^{\circ} \mathrm{F}$. have been recorded. Depending on the initial freshness of the herring and the amount of smoking it receives, the storage life of a kipper in summer is between $\mathrm{I}$ and 7 days. Some retailers order only once a week, so that much smoked fish is impaired by the time it is purchased.

It has been argued (Gerhardsen, I957) that in the declining market for smoked fish, a high level of quality should result from the keen competition for diminished sales, but in practice the competition is generally in price, which is not conducive to maintenance or improvement of quality.

\section{The use of fish for animal fodder}

The fish-meal industry in Britain and the other major trawling nations provide a valuable outlet for the wastage discarded in filleting white fish at the ports. However, 
the bulk of fish meal is produced from edible fish, chiefly of the herring type (Food and Agriculture Organization of the United Nations, I957). Some 4 million tons of fish a year (amounting to one-seventh of the world catch) are treated in this waymore than double the prewar figure. About three-quarters of this total is produced by large industries established to catch fish principally for 'reduction' in North America, Norway and south-west Africa. Two-thirds of the million tons landed in southern Africa and a third of the three-quarter million tons output of the Pacific coast of South America treated in this way are mostly exported to produce milk, eggs and bacon for the richest nations. In Britain, which is particularly dependent on imported meals (Woodham, r958), these products then compete with our own fish supplies. The economic value of this outlet is low owing to the inefficiency of the conversion of fish protein into animal protein and because it has to compete with meal made from fish offal.

This inequitable and wasteful distribution of natural resources is threatened by synthetic feeding materials. Countries with planned economies at least catch fish to eat it, Russia aiming to 'substitute synthetic raw materials for all food products used for industrial purposes by ... 196r' (Kruschchov, 1956). Even the protein from fish offal can be removed mechanically (Lantz, 1947, 1948) or by solventextraction (Guttmann \& Vandenheuvel, I957) to yield an edible flour.

Even more socially reprehensible is the growth of fish processing for household pets which now constitutes the largest section of the fish-canning industry in Britain, although some of this outlet has merely been transferred from the fresh-fish market. As much British-caught herring is now used for pet-food as is consumed as kippers in this country, together with 5,000 tons a year of white fish (British Trawlers' Federation, 1957).

This paper was prepared as part of the programme of the Department of Scientific and Industrial Research. (Crown Copyright Reserved.)

\section{REFERENCES}

Anonymous. (1956). Fish Tr. Gaz. no. 38 I9, p. 9 .

Anonymous. (1957). The Times, Sept. 7 th (London).

British Trawlers' Federation. (1957). Report on the British Fishing Industry. Distant Water Trawlers 1956. Hull, Grimsby, Fleetwood: The British Trawlers' Federation.

Central Statistical Office. (1957). Annu. Abstr. Statist., Lond., 94, I84.

Cutting, C. L. (1951). Biochem. Soc. Symp. no. 6, p. 86.

Cutting, C. L. (1955). Fish Saving. London: Leonard Hill.

Cutting, C. L. \& Bakken, K. (I957). Fish. Bull. F.A.O. 10, I I3.

Cutting, C. L. \& Burgess, G. H. O. (1958). F. Sci. Fd Agric. (In the Press.)

Cutting, C. L., Reay, G. A. \& Shewan, J. M. (I956). Spec. Rep. Fd Invest., Lond., no. 62.

Ehrenberg, A. S. C. \& Shewan, J. M. (1953). F. Sci. Fd Agric. 4, 482.

European Productivity Agency of the Organisation for European Economic Co-operation (1957). Fish Marketing in Western Europe since 1950. Paris: European Productivity Agency of the Organisation for European Economic Co-operation.

Food and Agriculture Organization of the United Nations. (1949). Fish. Bull. F.A.O. 2, 22.

Food and Agriculture Organization of the United Nations. (1957). Yearb. Fish. Statist. F.A.O.6.

Food and Agriculture Organization of the United Nations: Nutrition Division. (1953). Proc. Nutr. Soc. 17, r 53 .

Guttmann, A. \& Vandenheuvel, F. A. (1957). Progr. Rep. Atl. biol. Sta. no. 67, p. 29.

Herring Industry Board. (1957). Private communication.

Hitchcock, D. J. (1950). F. Parasit. 36, 232. 
Johnson, F. R. (1955). Private communication.

Khruschov, N. S. (1956). Report of the Central Committee to the 2oth Congress of the Communist Party, Moscow. Feb. 14, 1956, p. 37. London: Soviet News.

Lantz, A. W. (1947). Progr. Rep. Pacif. biol. Sta. no. 73, p. 58.

Lantz, A. W. (1948). Progr. Rep. Pacif. biol. Sta. no. 77, p. I 44.

Ministry of Agriculture, Fisheries and Food: National Food Survey Committee. (1956a). Studies in Urban Household Diets I 944-1 949. London: H.M. Stationery Office.

Ministry of Agriculture, Fisheries and Food: National Food Survey Committee. (1956b). Domestic Food Consumption and Expenditure 1954. London: H.M. Stationery Office.

Ministry of Agriculture, Fisheries and Food: National Food Survey Committee. (1957). Domestic Food Consumption and Expenditure 1955. London: H.M. Stationery Office.

Ministry of Agriculture, Fisheries and Food: National Food Survey Committee. (1958). Domestic Food Consumption and Expenditure 1956. London: H.M. Stationery Office.

Ministry of Food: National Food Survey Committee. (1953). Bull, Minist. Fd, Lond., no. 723, p. 8.

Myles, W. H., Reay, G. A. \& Farrer, H. E. M. (1945). Certain Aspects of the German Fishing Industry. British Intelligence Objectives Sub-Committee Final Report no. 493. London: H.M. Stationery Office.

Reay, G. A. (1951). Chem. \& Ind. p. гог9.

Shakespeare, W. (I598). Henry IV, Part I, ii, 4, 247.

Shewan, J. M. \& Ehrenberg, A. S. C. (1957). F. Sci. Fd Agric. 8, 227.

White Fish Authority. (1956), Report on Enquiry into the Costs of Distributing White Fish. London: White Fish Authority.

Woodham, A. A. (1958). Proc. Nutr. Sac. r7, 142.

\section{The use of fish flours as human food}

By The Nutrition Division, Food and Agriculture Organization of the United Nations, Rome, Italy

The prevalence of protein malnutrition in many parts of the world has been established during recent years. Its prevention depends on increasing the supply and consumption of proteins of appropriate nutritive value. Fish is among the important sources of such proteins and in many countries in which protein malnutrition is common there are great possibilities for expanding the fishing industry, depending not only on greater catches or yields, but also on better facilities for preservation, transport and marketing. At present frozen and canned fish are in general too expensive to be within the means of the mass of the people, though there are possibilities of developing cheaper forms of canning. Traditional methods of preserving fish, such as drying, smoking and curing, are widely used, but often do not secure a long storage life; here again there are possibilities for improvement which require investigation. All these approaches are of importance in increasing fish supply and consumption. There is still room, however, for the method discussed in this paper, namely the production of edible fish flour, to which the FAO Nutrition Division has devoted considerable attention.

The proteins of fish muscle are equivalent in biological value to those of animal muscle and milk. Fish flour, properly processed, retains the biological value of the original material. It keeps well and can without much difficulty be incorporated into local foods and dishes.

17 (2) 4 